\title{
Faith Development of high school students: Literature study
}

\author{
Yunita Sari, Susi Fitri, Aip Badrujaman
}

\author{
Universitas Negeri Jakarta \\ yunitasari_bk17s2@mahasiswa.unj.ac.id
}

Submitted : 28-09-2021, Revised : 29-04-2021, Accepted : 26-05-2021

\begin{abstract}
Spirituality and religiosity can be assets for adolescent development. The purpose of this study is to describe the development of faith that occurs in adolescents. This research is a literature study, where the data required in this study were obtained through analysis of various literature. The results of the study can be explained that adolescents who are at the high school education level and aged 14-18 years are at level 3, namely syntheticconventional faith. In this case, adolescents begin to develop formal operational thinking and begin to integrate learned faith values into a more rational faith system. For adolescents, this is an intellectual challenge to be able to become a foundation for understanding faith that will continue to develop in developing an understanding of faith in the future. This result implies the importance of guidance and counselling teachers to develop guidance and counselling programs that aim to help students achieve age-appropriate religious development.
\end{abstract}

Keywords: Faith Development, Fowler, Guidance and Counseling

\section{Introduction}

Students at the high school education level are in their middle adolescence. Students are the main subject for guidance and counselling teachers in providing services. The counselling guidance program that is made must pay attention to the characteristics of students because this will greatly affect the success of the process and results of guidance and counselling services. Guidance and counselling facilitate the development of students to achieve independence. Basically, the purpose of guidance and counselling is to make students independent. (Kartadinata, 2020)explains that healthy independence will grow through interactions between individuals, culture and a healthy environment. Then he explained that in order to develop independence, the purpose of guidance and counselling is not limited to the current problem-solving process, but is directed to prepare individuals to be able to face future problems and live life as members of society and the existence of Allah SWT.

Understanding the development of students is one of the efforts made by guidance and counselling teachers in order to be able to guide students optimally according to their strengths and weaknesses (Hardianto, 2014). One of the developmental tasks that must be achieved by students at the high school level is to achieve self-development as adolescents who believe in and fear God Almighty (Dirjen Guru dan Tenaga Pendidikan Kementerian Pendidikan dan Kebudayaan, 2016). Spirituality is increasingly being recognized as a cultural factor and treatment is very important, which can affect the relationship, process, or counselling outcome (Pattinama, 2018). Spirituality includes the concept of transcendence, self-actualization, purpose and purpose, wholeness, balance, sanctity, altruism, and awareness of higher powers (Good \& Willoughby, 2008).

In adolescence, apart from experiencing significant biological, psychological and sociological changes, they also experience an important stage in the development of faith. Based on the results of research, (Fowler, 1981) states that the development of faith focuses on motivation to find the meaning of life, both within and outside a religious context. Fowler (1981) believes that the theory of the development of faith is in line with the theory of development of identity. This is in line with Erikson's opinion which states that identity development and belief development are integral components of structural development theory (Koepke \& Denissen, 2012). 
The theory of faith development exists as a model of student development theory related to meaning, student identity, values, beliefs and spirituality. This is in line with research Tarar, Hassan, \& Keller (2017) which states that the theory of the development of faith focuses its attention on a more specific theory of human development which includes the spiritual and cognitive dimensions of students. Based on this, practitioners who are engaged in student service should study the implications of the theory of faith development because this theory can be useful in understanding students as whole persons.

\section{Methods}

This research uses a literature study, this study aims to broaden the scientific insight of guidance and counselling. Library research carried out in this study is based on: (a) problems in research can only be answered by reviewing various literature, (b) the need to understand new things that are developing in society, (c) data obtained through research from various literature can rely on in answering research problems (Zed, 2014). The data in the study were obtained through various sources of reading, including books, journals, research reports, encyclopedias, and other types that discuss the variables in this study. The results of the data in the study were processed qualitatively by analyzing data through data reduction steps, data presentation and drawing conclusions and verification of research data.

\section{Results and Discussion}

High school students who are usually 14-18 years old according to Fowler's belief development theory are at stage 3 of synthetic-conventional faith. At the synthetic-conventional stage, adolescents begin to develop formal operational thinking and begin to integrate the belief values that have been learned into a more rational belief system. Adolescents are still trying to adjust to other people's beliefs so that they are not able to analyze other people's beliefs. For adolescents, this is an intellectual challenge to become the basis for understanding beliefs that will continue in the development of understanding beliefs at the next stage.

The development of faith has five characteristics that qualitatively distinguish faithknowing from all other forms of constitutive knowledge. The results of the review that the author conducted were based on journals written by (Petersen, 2012) and also strengthened by research conducted by (Laszlo, 2016) with the research title Principles for a mould of an overnight "retreat" for high school students based on Fowler's Faith Development Theory and on some Hungarian Jesuits' experiences at Kurtabérc and other research conducted by (Lindon, 2017) about Faith Development as Experienced by Christian High School Seniors, they reveal five different faith-knowing qualitatively, which can the authors conclude as follows:

1. Constitutive knowledge in the development of faith, namely faith which consists of the nature of the relationship and the ultimate nature.

The ego and other people related to the ego are both constituted in and by the relationship itself. Apart from the nature of the relationship, there is also the nature of faith because faithknowing views a person and his group in relation to the boundaries and depth of experience as well as with the source/ centre of values and norms of all judgments and responsibilities in our lives.

2. Faith-Knowing is a typical mental operation

The point is that existential belief unites the various dimensions of knowledge that are different but interconnected, such as observation, feeling, imagination, rational judgment, assessment of commitment and action which, although different, must be viewed together.

3. The meaning of belief or faith-knowing is the understanding in which a person's personality is really involved and implied, even constituted. 
Fowler explains that faith-knowing does not only compose the object which he knows (for example, the image of the Transcendent), but also himself in the identity of himself as the subject in relation to the known.

4. One characteristic of faith-knowing is "belief as imagination"

Imaginal knowing is the most important power of faith knowing because the power of faith knowing imagines a scheme or structure, namely a comprehensive picture of the environment or the ultimate reality, which enables humans to understand all their experiences according to their most fundamental meaning and value.

5. Faith-knowing has two logics with different patterns, namely: "the logic of rational certainty" and "the logic of belief".

The logic of rational certainty refers to the activities of knowledge that are objective, impersonal and rational in nature. The logic of belief is a type of knowledge in which the subject himself plays the most important role. In the case of faith-knowing, we must not choose one or override the other, because these two logics do not cancel each other out. On the one hand, the logic of belief does not deny the logic of rational certainty, and on the other hand, faith knowing should not be regarded as irrational or even anti-rational.

Based on the five characteristics of existential belief above, it can be concluded that individual belief is a constitutive process of how he is committed to higher value centres that are reflected in patterns of daily life, as well as in past and future experiences. The development of trust is translated into seven structural aspects which are interrelated in an operational unit. The seven structural aspects must be explored one by one if we want to study the stage of trust as a process of giving meaning in more depth (Parker, 2009). Fowler outlines the seven structural aspects of the existential belief stage which the authors conclude as follows:

1. Aspect A, "Logic Form".

This aspect is influenced by the level of cognitive operation of Piaget's theory but this theory is insufficient for faith-knowing, so Fowler develops a theory of a broader rationality (the logic of belief) and a different view of the imagination.

2. Aspect B, "Role-taking".

Personal trust is not a completely private matter solely because the development of trust is influenced by the people around him (Parker, 2009). Our belief perspective is greatly influenced by the perspective of other people's beliefs, for example; the beliefs of parents, peers, religious leaders, even politicians.

3. Aspect C, "Forms of Moral Considerations".

Kohlberg's theory that has been developed through empirical research and theoretical reflection is used by Fowler for theories about self and personality. Fowler acknowledges that there are interesting parallels between moral development and the development of belief.

4. Aspect D, "Boundaries of Social Awareness".

The boundaries of social consciousness emphasize the extent and extent of the influence of other people and groups that are important to a person in an effort to construct and maintain his identity and social world at every stage of belief.

5. Aspect E, "Place of Priority".

This E aspect concerns what and who is recognized and accepted as an agency of authority for an individual. 


\section{Aspect F, "Forms of World Coherence".}

Fowler on this $\mathrm{F}$ aspect focuses our attention on the ways in which each stage of belief can contribute to a personal effort to create a whole meaning in an increasingly comprehensive and integral world view.

7. Aspect G, "Symbol Functions".

In this aspect, it is explained that in various stages individuals use and respond to all symbols and myths and how they are interpreted.

Faith Development Theory can provide a comprehensive picture that is very detailed about the transformations that occur in every aspect at a certain stage. The more advanced the development of belief, the tighter the integration between all these structural aspects will be. These seven aspects are used as the basis for the Faith Development Interview (FDI) as described by (Leak et al., 1999). The explanation of the stages of the development of belief at each stage will use the seven aspects above.

James W. Fowler is the initiator of the Theory of Faith Development, since 1972. Theory of faith development is a scientific psychological effort to describe and analyze the entire dynamics of the development process of the stages of belief empirically and theoretically. The following are the stages of belief development:

\section{Stage 0: Primal Faith}

This stage occurs as a stage or pre-stage (prestage), that is, babies 0 to 2 or 3 years old. This stage is marked by a taste that is preverbal to the conditions of existence, that is, elementary trust and loyalty to all people and the environment that cares for the baby. As well as the description of the final power that can be trusted, to overcome the fear that arises in young children, as a result of the threat of deprivation of life and separation from their caregivers.

2. Stage 1: Intuitive Belief - Projective

The first stage of development is 2 to 6 years of age. The child's thinking process is still running slowly. Children engrossed in imitating adults who are important to them as a source of absolute authority. Intuitive (intuition) is a term for the ability to understand something without going through rational reasoning and intellectuality. It is called "projectiveintuitive" because the world of children's experiences is structured based on strong sensoryemotional impressions, so that perceptions and feelings give rise to deep and gradual deep and concrete intuitive and concrete images. The divinity of this period was understood preanthropomorphically and magically on the basis of purely physical qualities.

3. Stage 2: Mystical Beliefs - Literal

Children aged 6-11 years. At this time children have new social cognitive abilities that allow taking (transfer) of other people's perspectives and roles, so children overcome the limitations of egocentrism and expand the reach of their social cognitive world. At the mystical-literal stage, God is seen as a person, like a parent or a ruler who acts with a consistent, firm and if necessary, stern attention. It can be concluded that Allah is considered as a king who makes laws. At the end of the stage of mystical-literal belief, children have a new perspective in seeing God, no longer as parents or kings who are full of power and are far from humans even though they are still fair, but more so as a "personal friend" who is close and intimate with him. In other words, the center and source of value, truth, and power that tend to become more "personal".

4. Stage 3: Synthetic Trust - Conventional

At the age of 12 or 13 years, there is a change in the early teens to about 20 years. emerge various kinds of cognitive abilities that encourage children to revisit their views. The image of Allah in adolescents is structured according to the paradigm of "mutual interpersonal relationships". God is felt and viewed according to the aspect of friendship that supports and guides a person. Faith - knowing becomes the core process of the power of synthesis and 
the formation of identity. The duty and function of belief at this time is as a central force that animates and animates the entire process of forming self-identity.

5. Stage 4: Individual Trust - Reflective

This stage appears at the age of 20 years and over. Individuals experience deep and comprehensive changes in their lives. At this time, individuals will be responsive and critical of ideological and charismatic leaders. It is called individuative-reflective because individuals develop trust as a result of solely critical reflection. When all these unspoken religious beliefs are expressed explicitly and examined critically, we find many elements of conventional beliefs, values, teachings, and myths and stories from religious traditions that cannot be accepted by reason.

6. Stage 5: Conjunctive Belief

This stage appears in middle age and thereafter, the minimum age is around 35 or 40 years. Fowler (in Hasan, 2018), chooses a conjunctive term which means connecting, binding with one another. The term conjunctive refers to all things that are contradictory which at the previous stage were felt to be separate from one another and impossible to reconcile, now they are united in a higher, dynamic, and open whole. . At the conjunctive belief stage, belief in this stage is personally and critically perceived as the greatest and most important existential force, far beyond all limited human power. The ultimate source of authority is Allah Himself.

7. Stage 6: Trust Referring to Universality

This stage of belief is actually rare, and if it occurs it generally occurs after the age of 30 years. This stage usually appears in major figures in the history of religion. The person empties himself, but at the same time experiences himself as a being rooted in God, and this is what becomes the center of perspective for the individual. The universalizers carry the burden of being "messengers of Allah" in the midst of the world. Having the responsibility to be an example and a reference point for the pattern of fellowship between God and humans.

Fowler (Haggray, 1993) makes this stage of development of belief unlike other developmental models, a person may remain at a certain stage and not rise to the next stage. Fowler made an assessment of the majority of adults in the United States and found that their belief stage is at stage 3 . The reasons given by Fowler for why the majority of adults in America are at stage 3 are influenced by low levels of belief, religious environment and social environment.

One of the characteristics of the development stage of trust is that all aspects are structural in which one aspect and the other are interrelated in an operational unit. If we want to study the development stage of trust as a process of giving meaning in more depth, then the various structural aspects must be explored one by one. Fowler (Hasan \& Fowler, 2018); Ashdown, Brien K., \& Gibbsons, n.d., 2012) explains the relationship between the seven structural aspects and the stages of trust development in the table below:

Tabel 1: Faith Stages by Aspects

\begin{tabular}{|c|c|c|c|c|c|c|c|}
\hline \multirow[t]{2}{*}{ STAGE } & \multicolumn{7}{|c|}{ ASPECT } \\
\hline & $\mathrm{A}$ & $\mathrm{B}$ & $\mathrm{C}$ & $\mathrm{D}$ & $E$ & $\mathrm{~F}$ & $\mathrm{G}$ \\
\hline I & Preoperational & $\begin{array}{l}\text { Rudimentary } \\
\text { empathy } \\
\text { (egocentric) }\end{array}$ & $\begin{array}{l}\text { Punisment- } \\
\text { reward }\end{array}$ & $\begin{array}{l}\text { Family, } \\
\text { primal } \\
\text { others }\end{array}$ & $\begin{array}{l}\text { Attachment } \\
\text { /dependence } \\
\text { relationships, } \\
\text { Size, } \\
\text { Power,visible } \\
\text { symbols of } \\
\text { authority }\end{array}$ & Episodic & $\begin{array}{l}\text { Magical- } \\
\text { Numinous }\end{array}$ \\
\hline II & $\begin{array}{l}\text { Concrete } \\
\text { Operational }\end{array}$ & $\begin{array}{l}\text { Simple } \\
\text { perspective } \\
\text { taking }\end{array}$ & $\begin{array}{l}\text { Instrumental } \\
\text { hedonism } \\
\text { (Reciprocal } \\
\text { fairness) }\end{array}$ & $\begin{array}{l}\text { "those like } \\
\text { us"(in } \\
\text { familial, }\end{array}$ & $\begin{array}{l}\text { Incumbents of } \\
\text { authority roles, } \\
\text { salience } \\
\text { increased by }\end{array}$ & $\begin{array}{l}\text { Narrative- } \\
\text { Dramatic }\end{array}$ & $\begin{array}{l}\text { One- } \\
\text { dimensional; } \\
\text { literal }\end{array}$ \\
\hline
\end{tabular}




\begin{tabular}{|c|c|c|c|c|c|c|c|}
\hline & & & & $\begin{array}{l}\text { ethnic, } \\
\text { racial,class } \\
\text { and } \\
\text { religious } \\
\text { terms) }\end{array}$ & $\begin{array}{l}\text { personal } \\
\text { relatedness }\end{array}$ & & \\
\hline III & $\begin{array}{l}\text { Early Formal } \\
\text { Operations }\end{array}$ & $\begin{array}{l}\text { Mutual } \\
\text { Interpersonal }\end{array}$ & $\begin{array}{l}\text { Interpersonal } \\
\text { expectations } \\
\text { and } \\
\text { concordance }\end{array}$ & $\begin{array}{l}\text { Composite } \\
\text { of groups in } \\
\text { which one } \\
\text { has } \\
\text { interpersonal } \\
\text { relationships }\end{array}$ & $\begin{array}{l}\text { Consensus of } \\
\text { valued groups } \\
\text { and in } \\
\text { personally } \\
\text { worthy } \\
\text { representatives } \\
\text { of belief-value } \\
\text { traditions }\end{array}$ & $\begin{array}{l}\text { Tacit system, } \\
\text { Felt } \\
\text { meanings } \\
\text { symbolically } \\
\text { mediated } \\
\text {,globally } \\
\text { held }\end{array}$ & $\begin{array}{l}\text { Symbols } \\
\text { multi- } \\
\text { dimensional } \\
\text {;evocative } \\
\text { power } \\
\text { inheres in } \\
\text { symbol }\end{array}$ \\
\hline IV & $\begin{array}{l}\text { Formal } \\
\text { Operations } \\
\text { (Dichotomizing) }\end{array}$ & $\begin{array}{l}\text { Mutual, with } \\
\text { self-selected } \\
\text { group or } \\
\text { class- } \\
\text { (societal) }\end{array}$ & $\begin{array}{l}\text { Societal } \\
\text { perspective, } \\
\text { Reflective } \\
\text { relativism or } \\
\text { class-biased } \\
\text { universalism }\end{array}$ & $\begin{array}{l}\text { Ideologically } \\
\text { compatible } \\
\text { communitie } \\
\text { s with } \\
\text { congruence } \\
\text { to self- } \\
\text { chosen } \\
\text { norms and } \\
\text { insights }\end{array}$ & $\begin{array}{l}\text { One's own } \\
\text { judgment as } \\
\text { informed by a } \\
\text { self-ratified } \\
\text { ideological } \\
\text { perspective. } \\
\text { Authorities and } \\
\text { norms must be } \\
\text { congruent with } \\
\text { this }\end{array}$ & $\begin{array}{l}\text { Explicit } \\
\text { system, } \\
\text { conceptually } \\
\text { mediated, } \\
\text { clarity about } \\
\text { boundaries } \\
\text { and inner } \\
\text { connections } \\
\text { of system }\end{array}$ & $\begin{array}{l}\text { Symbols } \\
\text { separated } \\
\text { from } \\
\text { symbolized. } \\
\text { Translated } \\
\text { (reduced) to } \\
\text { ideations } \\
\text {.Evocative } \\
\text { power } \\
\text { inheres in } \\
\text { meaning } \\
\text { conveyed by } \\
\text { simbols }\end{array}$ \\
\hline $\mathbf{V}$ & $\begin{array}{l}\text { Formal } \\
\text { Operations } \\
\text { (dialectical) }\end{array}$ & $\begin{array}{l}\text { Mutual with } \\
\text { groups,clases } \\
\text { and traditions } \\
\text { "other"than } \\
\text { one's own }\end{array}$ & $\begin{array}{l}\text { Prior to } \\
\text { society,Prin } \\
\text { cipled } \\
\text { higher law } \\
\text { (universal } \\
\text { and critical) }\end{array}$ & $\begin{array}{l}\text { Extends } \\
\text { beyond } \\
\text { class norms } \\
\text { and intersts } \\
\text { Diciplined } \\
\text { ideological } \\
\text { vulnerabilit } \\
\text { y to "truths" } \\
\text { and } \\
\text { "claims" of } \\
\text { outgroups } \\
\text { and other } \\
\text { traditions }\end{array}$ & $\begin{array}{l}\text { Dialectical } \\
\text { joining of } \\
\text { judgment- } \\
\text { experience } \\
\text { processes with } \\
\text { reflective } \\
\text { claims of others } \\
\text { and of various } \\
\text { expressions of } \\
\text { cumulative } \\
\text { human wisdom }\end{array}$ & $\begin{array}{l}\text { Multysistemic } \\
\text { and } \\
\text { conceptual } \\
\text { mediation }\end{array}$ & $\begin{array}{l}\text { Posterical } \\
\text { rejoinning } \\
\text { of } \\
\text { irreducible } \\
\text { symbolic } \\
\text { power and } \\
\text { ideational } \\
\text { meaning. } \\
\text { Evocative } \\
\text { power } \\
\text { inherent in } \\
\text { the reality in } \\
\text { and beyond } \\
\text { symbol and } \\
\text { in the power } \\
\text { of } \\
\text { unconscious } \\
\text { processes in } \\
\text { the self }\end{array}$ \\
\hline VI & $\begin{array}{l}\text { Formal } \\
\text { Operations } \\
\text { (Synthetic) }\end{array}$ & $\begin{array}{l}\text { Mutual, with } \\
\text { the } \\
\text { commonwealth } \\
\text { of being }\end{array}$ & $\begin{array}{l}\text { Loyalty to } \\
\text { being }\end{array}$ & $\begin{array}{l}\text { Identificatio } \\
\text { ns with the } \\
\text { species, } \\
\text { Transnarciss } \\
\text { istic love of } \\
\text { being }\end{array}$ & $\begin{array}{l}\text { In a personal } \\
\text { judgment } \\
\text { informed by the } \\
\text { experiences and } \\
\text { truths of } \\
\text { previous stages, } \\
\text { purified of } \\
\text { egoic striving, } \\
\text { and linked by } \\
\text { disciplined } \\
\text { intuition to the } \\
\text { principle of } \\
\text { being }\end{array}$ & $\begin{array}{l}\text { Unitive } \\
\text { actuality felt } \\
\text { and } \\
\text { participated } \\
\text { unity of } \\
\text { "One beyond } \\
\text { the many" }\end{array}$ & $\begin{array}{l}\text { Evocative } \\
\text { power of } \\
\text { symbols } \\
\text { actualized } \\
\text { through } \\
\text { unification } \\
\text { of reality } \\
\text { mediate by } \\
\text { symbols and } \\
\text { the self }\end{array}$ \\
\hline
\end{tabular}

The level of development of a person's beliefs has a considerable impact on his outlook on life. Two individuals who have the same age are not necessarily the same in the level of development of their beliefs because each individual is unique and is influenced by their view of Allah, also influenced by the people around the individual (family, colleagues, society) and the culture owned by the individual 


\section{Conclusions and Suggestions}

Based on the results of the research, it can be concluded that high school students who are included in the category of adolescents where they are in the development of their faith in the third stage are called synthetic terms, meaning that the diversity of content and beliefs has not yet come together so that they can form a complete unity. This belief pattern is also called conventional, because it is cognitively, affective, and socially important for individuals to adjust to other people who are important to themselves and the majority of people.

This study suggests that the development of faith data can be used by guidance and counselling teachers to create guidance and counselling programs that aim to help students achieve the Competency Standards for Student Independence. Apart from that, counselling guidance teachers must also be aware of how the development of faith and the crisis of faith has a significant impact on students. Guidance and counselling teachers can use guidance and counselling programs to help students achieve age-appropriate faith development.

\section{References}

Ashdown, Brien K., \& Gibbsons, J. L. (n.d.). Faith Development and Collectivism among Emerging Adults in Guatemala and the United states. Advances In Pshycology Study, 1 no.3.

Dirjen Guru dan Tenaga Pendidikan Kementerian Pendidikan dan Kebudayaan. (2016). Panduan operasional Penyelenggaraan Bimbingan dan Konseling di Sekolah Menengah Atas (SMA).

Fowler, J. W. (1981). Stage of Faith, The psichology of Human Development and the Quests For Meaning. Harper Collins.

Good, M., \& Willoughby, T. (2008). Adolescence as a sensitive period for spiritual development. Child Development Perspectives, 2(1), 32-37. https://doi.org/10.1111/j.1750-8606.2008.00038.x

Haggray, D. A. (1993). A description of the faith development of five students attending a church-related college.

Hardianto, P. D. (2014). Pentingnya Pendidikan Interreligiusitas. E Jurnal USD, 03(01).

Hasan, J., \& Fowler, J. W. (2018). Sumbangsih Pemikiran James W. Fowler dalam Pendidikan Agama di Perguruan Tinggi Indonesia. Respons: Unika Atma Jaya, 23(02), 185-204.

Kartadinata, S. (2020). Teori Bimbingan dan Konseling. UPI Bandung.

King, P. E., \& Roeser, R. W. (2009). Religion and Spirituality in Adolescent Development. In Handbook of Adolescent Psychology (Issue October). https://doi.org/10.1002/9780470479193.adlpsy001014

Koepke, S., \& Denissen, J. J. A. (2012). Dynamics of identity development and separationindividuation in parent-child relationships during adolescence and emerging adulthoodA conceptual integration. Developmental Review, 32(1), 67-88.

Laszlo, E. (2016). Princeples for a mold of an overnight "retreat" for high school students based on Fowler's Faith development Theory and on some Hungarian Jesuits 'experiences at kurtabec. Boston college School of Theology and Ministry.

Leak, G. K., Loucks, A. A., \& Bowlin, P. (1999). Development and initial validation of an objective measure of faith development. International Journal of Phytoremediation, 21(1), 105-124. https://doi.org/10.1207/s15327582ijpr0902_2 
Lindon, patrick pauoa K. (2017). Faith Development as Experienced by Christian High School seniors. Liberty University.

Parker, S. (2009). Faith development theory as a context for supervision of spiritual and religious issues. Counselor Education and Supervision, 49(1), 39-53. https://doi.org/10.1002/j.1556-6978.2009.tb00085.x

Pattinama, C. (2018). Perkembangan Kepercayaan Mahasiswa dan Perilaku Belajarnya. 3, 35-42. https://doi.org/10.31219/osf.io/hq4n6

Petersen, B. R. (2012). Application of Faith Development Theory for Undestanding Students'Transformational Learning as A Result of Bonfire at Texas A \& M University. Texas A \& M.

Tarar, A. H., Hassan, S. S., \& Keller, B. (2017). Muslim Faith in Pakistan: A FaithDevelopment View on Fundamentalist to Mature Orientations. Archive for the Psychology of Religion, 39(1), 27-60. https://doi.org/10.1163/15736121-12341334

Zed, M. (2014). Metode Penelitian Kepustakaan. Yayasan Pustaka Obor Indonesia. 